New Developments in Sheep Production

Occasional Publication No. 14-British Society of Animal Production 1990

edited by C. F. R. Slade and T. L. J. Lawrence

\title{
EVALUATION OF A PERENNIAL RYEGRASS AND SMALL-LEAVED ClOVER SWARD WITHOUT NITROGEN FERTILIZER UNDER CONTINUOUS SHEEP GRAZING AT CONTROLLED SWARD HEIGHT
}

\author{
J. E. VIPOND ${ }^{1}$, G. SWIFT ${ }^{1}$, T. H. McCLELLAND ${ }^{1}$ and J. A. MILNE ${ }^{2}$ \\ ${ }^{1}$ Edinburgh School of Agriculture, West Mains Road, Edinburgh EH9 $3 J G$ \\ ${ }^{2}$ Macaulay Land Use Research Institute, Bush Estate, Penicuik, Midlothian EH26 OPY
}

\section{INTRODUCTION}

$\mathbf{M}$ ost lamb production in the United Kingdom comes from the utilization of sown and indigenous pastures, much of it on land of national strategic importance with respect to scenery and the conservation of wildlife and water resources. On arable farms the grass break is seen as a welcome relief from intensive arable farming practices. The objective of this research was to examine the role of white clover as a food and pasture component and how it can be managed, without artificial nitrogen fertilizer, to produce lean lamb.

In the past a combination of unsuitable establishment practice for clover, incorrect choice of grass and clover varieties and haphazard grazing management has masked the potential of white clover to persist in the pasture and to fix atmospheric nitrogen worth $f 60$ /ha per year. Previous investigations have established that under intensive continuous sheep grazing the smallleaved white clover $\mathrm{S} 184$ is capable of dry matter yields of over $2 t / h a$, which is double that of the larger leaved varieties comonly used but which tend to die out under continuous sheep grazing. Choice of a compatible companion ryegrass variety is an important consideration. Based on the performance recorded in National List Variety Trials, Condesa, a tetraploid variety of open sward structure favourable to clover stolons spread was chosen as a companion grass.

\section{MATERIAL AND METHODS}

\section{Pasture establishment and management}

Swards were established by direct seeding in May 1987 with no seedbed nitrogen $(\mathrm{N})$ being applied and were evaluated over two grazing seasons. Two grazing paddocks of 1.4 ha Condesa + S184 and two paddocks of 1 ha Condesa were maintained at a constant sward surface height in a target range of 4 to $6 \mathrm{~cm}$ measured by swardstick from mid April to 30 June by a put and take system using Mule ewes with Suffolk $\times$ twin lambs. The live-weight data presented cover the grazing period from turn-out in mid April to 30 June and from one replicate only until 31 July which equates with the pre-weaning period on lowland farms. Fertilizer applications of $150 \mathrm{~N}: 30 \mathrm{P}_{2} \mathrm{O}_{5}: 30 \mathrm{~K}_{2} \mathrm{O}$ per ha for grass and $0 \mathrm{~N}: 45$ $\mathrm{P}_{2} \mathrm{O}_{5}: 45 \mathrm{~K}_{2} \mathrm{O}$ per ha for grass and clover swards were used over the grazing period.

\section{RESULTS}

\section{Sward characteristics and observed changes}

Mean consecutive 3-weekly sward surface heights attained were $7 \cdot 8,6 \cdot 7,4.8,5 \cdot 1$ and $4.8 \mathrm{~cm}$ in year 1 and $5 \cdot 4,5 \cdot 2,5 \cdot 0,4 \cdot 5$ and $3 \cdot 9 \mathrm{~cm}$ in year 2 with no significant differences between swards. Swards were rested from grazing from 1 September to 25 October in year 1 . Proportions of clover in herbage dry matter monthly from April were $0.04,0.05,0.11$ and 0.24 in year 1 and $0.14,0.24,0.27$ and 0.36 in year 2 , indicating that continuous grazing at about $6 \mathrm{~cm}$ height with no applied $\mathrm{N}$ favoured clover development and that the clover overwintered satisfactorily. To put the proportions of clover in the experimental pastures into perspective, pastures with over $0 \cdot 1$ clover were recorded in only two grazing fields from 100 surveyed on 'rearing with arable' farms in the East of Scotland. The predominant feature of the experimental swards was the continuous network of clover stolons and leaf with a dense clover stand appearing immediately grazing pressure was reduced. Ryegrass tiller numbers (thousands per $\mathrm{m}^{2}$ ) on the Condesa and Condesa + S184 swards averaged 11.3 and 8.8 in year 1 and 12.7 and 8.5 in year 2 . The continuing high tiller population of this recently introduced tetraploid variety when sown alone and grazed hard is an improvement on earlier tetraploid varieties which were less persistent. Lower Poa annua content $(0.03$ v. 0.05$)$ in the clover-dominant sward was attributed to the vigour and competition of the clover, which was enhanced by the absence of applied $\mathrm{N}$, and to the lower tiller density associated with the tetraploid companion grass. 
TABLE 1

Daily live-weight gain of ewes and lambs on swards of grass + nitrogen $(N)$ or grass + clover

\begin{tabular}{|c|c|c|c|c|}
\hline \multirow[b]{2}{*}{ Sward type } & \multicolumn{2}{|c|}{1988 (April to July) } & \multicolumn{2}{|c|}{1989 (April to July) } \\
\hline & $\begin{array}{c}\text { Ewe live-weight } \\
\text { gain (g/day) }\end{array}$ & $\begin{array}{l}\text { Lamb live-weight } \\
\text { gain (g/day) }\end{array}$ & $\begin{array}{c}\text { Ewe live-weight } \\
\text { gain (g/day) }\end{array}$ & $\begin{array}{c}\text { Lamb live-weight } \\
\text { gain (g/day) }\end{array}$ \\
\hline Grass $+\mathbf{N}$ & -48 & 280 & +13 & 290 \\
\hline Grass + clover & +21 & 327 & +102 & 346 \\
\hline Significance & $*$ & $* * *$ & $* *$ & $* *$ \\
\hline s.e.d. & $32 \cdot 6$ & $10 \cdot 9$ & $19 \cdot 0$ & $11 \cdot 5$ \\
\hline
\end{tabular}

\section{Animal performance}

Lambs on grass + clover swards gained $327 v$. $280 \mathrm{~g} /$ day for grass only swards in year 1 and $346 v$. $290 \mathrm{~g} /$ day in year 2 . Ewe weight changes were $+21 v$. -48 and $+102 v .+13 \mathrm{~g} /$ day respectively (see Table 1 ).

Effects of the grass/clover swards on individual animal performance were thus similar in both years, i.e. $+50 \mathrm{~g} /$ day gain in lambs and $+80 \mathrm{~g} /$ day gain in ewes, despite there being more clover present in the sward in year 2. One interpretation of these results is that sheep select to graze those parts of the swards which contain a higher proportion of clover relative to the pasture as a whole and thus can demonstrate the same performance

enhancement over a range of clover content of pasture. Results from estimated levels of total output per ha however suggest that whilst individual animal performance can be enhanced by a relatively low level of clover in pastures, to achieve comparable levels of output per ha of fertilized grass, sward levels of proportionately over $\mathbf{0 . 2}$ clover in sward dry matter are required (see Table 2).

In the first grazing year, which was wetter, there was a greater output per ha from the grass $+\mathrm{N}$ sward attributable to the higher overall stocking rate achieved, which was 21 ewes per ha $v .13$ ewes per ha on the grass + clover sward. Average stocking density of 30 ewes per
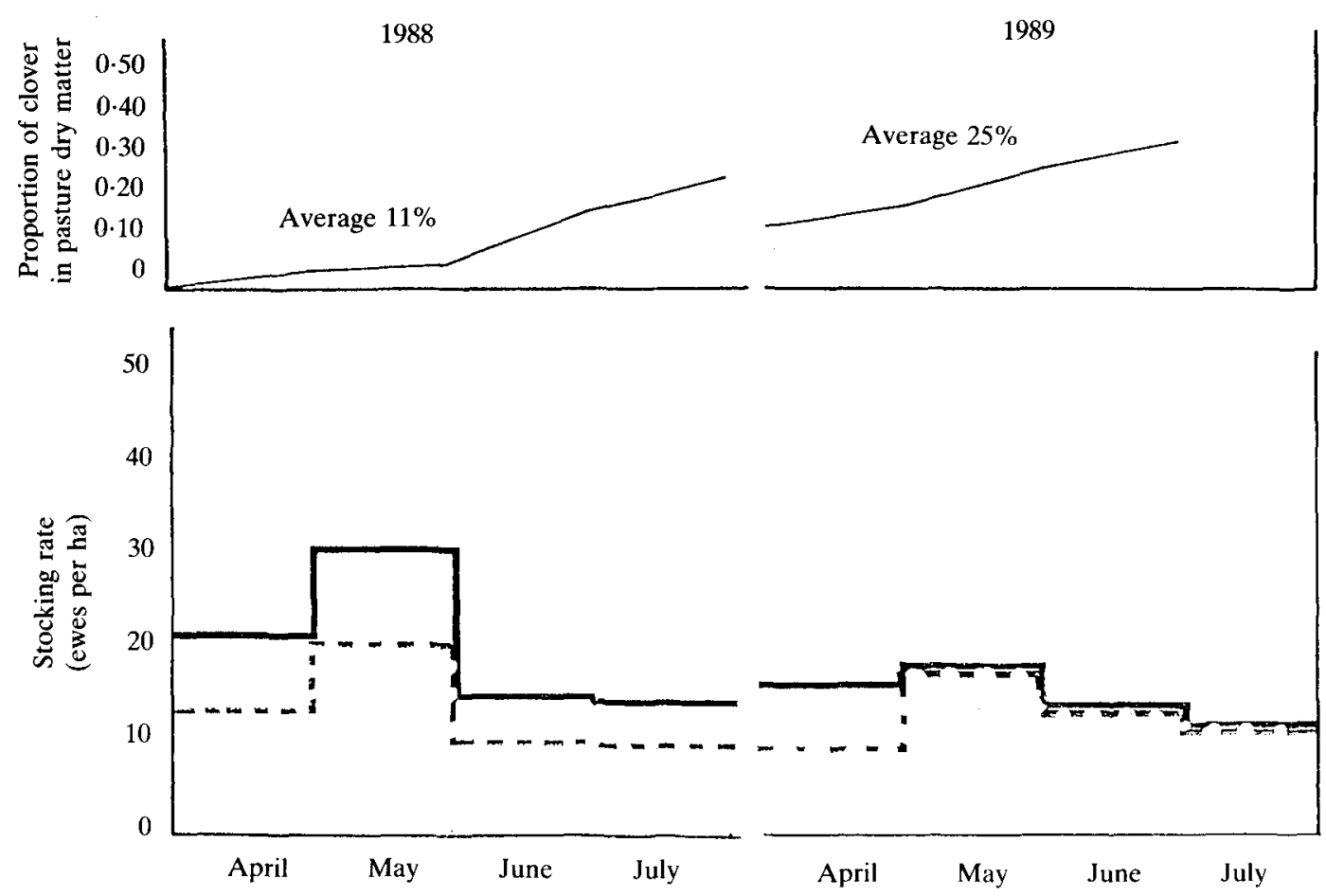

FIG. 1. Stocking rate of ewes on grass + nitrogen (____ $)$ or grass + clover (- - - ) swards maintained at constant sward heights and clover content of grass + clover swards. 
TABLE 2

Estimated live-weight gain ( $\mathrm{kg}$ per ha) of grass + nitrogen $(N)$ and grass + clover swards

\begin{tabular}{lrrrrrrr}
\multicolumn{2}{c}{1988 (April to July) } & \multicolumn{3}{c}{1989 (April to July) } \\
\cline { 2 - 2 } & Ewes & Lambs & Total & Ewes & Lambs & Total \\
Grass $+\mathrm{N}$ & -113 & +1107 & 994 & +21 & +908 & 929 \\
Grass + clover & +31 & +775 & 806 & +154 & +997 & 1151
\end{tabular}

ha was required in May to control sward height which was temporarily above the target range of 4 to $6 \mathrm{~cm}$ (see Figure 1). Ewes lost weight, particularly during the period when sward height was being reduced. In the second grazing year, which was drier, the overall stocking rates of grass $+\mathrm{N}$ and grass + clover swards were 15 and 13.5 ewes per ha respectively but the improved performance of ewes and lambs on the clover swards resulted in higher output per ha for grass + clover swards. The lower output of the grass $+\mathrm{N}$ sward in year 2 compared with year 1 was attributed to lack of response to applied $\mathrm{N}$ owing to a moisture deficit; the grass + clover sward stayed greener during the dry weather and appeared less affected by the moisture deficit. Total production on the clover sward in the 2 nd year was higher $(1151 \mathrm{~kg})$ than in the previous year $(806 \mathrm{~kg})$ and this can be attributed to the higher proportion of clover in the sward $(0 \cdot 25 v \cdot 0 \cdot 11)$. Annual $\mathrm{N}$ fixation is closely dependent on annual clover dry matter production. Ewe and lamb performance was enhanced in the 2 nd year during the favourable weather conditions but the relative improvement due to clover was similar. Ewe performance was better in the 2 nd year because swards did not exceed target heights and then have to be controlled by high stocking rates.

\section{DISCUSSION}

The results of these experiments show that in clover based systems for lowland/upland farms the enhanced lamb weight gain obtained from the grass/clover swards ( +5 to $6 \mathrm{~kg}$ by $31 \mathrm{July}$ ) makes it possible for twin lambs to be finished by mid August (within 4 months of birth) at acceptable stocking rates (13.5 ewes per ha, 5.5 ewes per acre). At current $N$ usage levels of $160 \mathrm{~kg} \mathrm{~N}$ per ha (Meat and Livestock Commission, 1988) reductions in $\mathrm{N}$ fertilizer costs of $£ 58$ per ha or $£ 4.32$ per ewe could be achieved based on the results obtained on grass/clover pastures using the varieties evaluated in these experiments. Systems are envisaged where control of pasture height is achieved by 'put and take' from a cuttable buffer area which can be used for silage conservation.

Clover/grass swards are generally thought to be more variable than grass swards in terms of production. With these swards, however, the clover/grass swards were easier to manage, having a lower peak stocking density in the early summer. Relative to the grass swards the monthly ewe and twin lamb carrying capacity of grass and clover paddocks from mid April were 0.45, 0.70, 0.70 and 0.71 in year 1 and $0.84,1.00,0.97$ and 1.04 in year 2 .

At the altitude of the Beechgrove site $(180 \mathrm{~m})$ in south-east Scotland the clover-dominant swards achieved the same stock carrying capacity about 14 days later than the grass swards which were fertilized in late March. As the proportion of clover in the sward increased, the proportion of spring herbage production increased suggesting many of the perceived problems of relying on clover for early growth may be attributable to low clover contents of pastures. The extra gain $(+50 \mathrm{~g} /$ day) achieved on the grass/clover paddocks could enable the lambing date of ewes on the grass/clover swards to be delayed by 14 days without reducing lamb weight at weaning (100 days) and thus could avoid a spring deficit of grass.

The results are applicable to farms in areas where groundwater pollution of water resources with $\mathrm{N}$ from fertilizer has resulted in restrictions on the use of $\mathrm{N}$ fertilizers. They could also be applied where extensification schemes involving a reduction of stocking rates by $20 \%$ are operated.

\section{REFERENCES}

Meat and Livestock Commission. 1988. Sheep Yearbook. Meat and Livestock Commission, Milton Keynes. 